\title{
Perancangan Interior Ruang Asrama Santriwati Di Pesantren Al - Munawir Krapyak
}

\author{
Martino Dwi Nugroho \\ Fakultas Seni Rupa, Institut Seni Indonesia Yogyakarta \\ joglo.tino@gmail.com
}

\begin{abstract}
Abstrak- Komplek R1 merupakan salah satu asrama santriwati di Pesantren Al-Munawwir, Krapyak, Yogyakarta. Dari keseluruhan ruang, kamar tidur merupakan ruang yang paling sering digunakan santriwati untuk beraktivitas sehingga memungkinkan terjadinya penyesuaian-penyesuaian terhadap seting yang ada. Penyesuaian dilakukan dengan cara mengubah perilaku agar sesuai dengan lingkungan (adaptasi) ataupun mengubah lingkungan agar sesuai dengan perilaku (adjustment). Masalah penelitian ini adalah bagaimana kondisi kamar tidur komplek R1 dan bagaimana perilaku penyesuaian santriwati di dalamnya. Tujuan penelitian ini adalah untuk mengetahui perilaku adaptasi dan adjustment santriwati pada kamar tidur komplek R1. Penelitian ini berdasarkan pendekatan kualitatif (behavioral setting) dengan metode pengumpulan data melalui wawancara, observasi, dan behavioral mapping. Data di analisis secara kualitatif rasionalistik menuju suatu kesimpulan peneliti. Hasil penelitian menunjukkan bahwa santriwati melakukan dua macam penyesuaian, namun perilaku adaptasi lebih dominan karena adanya kesadaran tentang nilai-nilai kesederhanaan yang ditanamkan dipesantren dan falsafah "nrimo ing pandhum". Kesadaran tentang nilai-nilai tersebut menyebabkan rendahnya upaya santriwati untuk mengubah lingkungan. Perilaku penyesuaian santriwati juga dipengaruhi sikap kemuslimahannya yang dikonstruksi oleh kultur agama.
\end{abstract}

Kata kunci: perilaku; adaptasi; adjustment; santriwati; kamar tidur

\section{PENDAHULUAN}

Pesantren merupakan lembaga pendidikan yang berpengaruh dalam penyebaran nilainilai Islam dan nilai-nilai morak (akhlak) di Indonesia. Menurut Suryanegara (2009:17), sejarah kemerdekaan Indonesia mencatat bahwa para ulama dan santri berperan serta memimpin perlawanan bersenjata terhadap penjajah sehingga oleh George dalam Suryanegara (2009:19) dikatakan bahwa pada masa penjajahan, rakyat menjadikan Islam sebagai simbol kesatuan dan persatuan. Semangat yang dibangun oleh ulama kepada santrinya tidak lepas dari nilai-nilai Islam yang ditanamkan melalui pendidikan pesantrenpesantren pada masa itu.
Selain KH. Ahmad Dahlan, Yogyakarta juga melahirkan sosok $\mathrm{KH}$. Moenawir, seorang ulama berpengaruh dimana pesantren yang beliau dirikan sejak tahun 1910 telah melahirkan ratusan ulama ahli Qur'an terkemuka di berbagai daerah di Indonesia. Atas sumbangsih jasa pendirinya, sejak tahun 1976, pesantren ini kemudian disebut Pondok Pesantren Al-Munawir yang berlokasi di Krapyak, Yogyakarta. Saat ini Pesantren AlMunawir memiliki ribuan santri dan santriwati dari berbagai wilayah di Indonesia bahkan luar negeri. Selama menempuh pendidikan pesantren, santri dan santriwati ditempatkan secara terpisah di asrama-asrama atau biasa disebut kompleks. 
Beberapa permasalahan yang dapat diidentifikasi antara lain : 1) bagaimana merancang ruang asrama santriwati yang mengakomodasi kebutuhan akan privasi dan personal space; 2) bagaimana merancang perabot yang efisien dan fungsional pada ruang asrama santriwati R1 dimana penghuninya banyak sedangkan ruangan terbatas.

\section{METODE}

Penelitian ini menggunakan metode kualitatif dengan pengumpulan data melalui data literatur terkait spasial ruang asrama dan data ergonomis, data lapangan non fisik berupa data proyek standarisasi ruang asrama dan keinginan klien, dan data lapangan fisik terkait lokasi, bentuk dan luas denah bangunan

Selanjutnya data dianalisis secara kualitatif rasionalistik untuk mendapatkan suatu kesimpulan berdasarkan rancangan permasalahan tersebut di atas.

\section{HASIL DAN PEMBAHASAN}

\section{Adaptasi dan Adjustment}

Wohlill dalam Iskandar (2012: 46) mengemukakan bahwa dalam hubungan antara manusia dengan lingkungan ada tiga kategori, yaitu stimulasi penginderaan, stimulasi sosial, stimulasi pergerakan.
Manusia tidak menginginkan stimulasi baik stimulasi penginderaan, stimulasi sosial, stimulasi pergerakan yang berlebihan ataupun kekurangan. Manusia akan merasa tidak nyaman dan terganggu apabila menerima stimulus yang kurang ataupun berlebih.

Interaksi manusia terhadap lingkungan tidak sebatas dengan adaptasi perilaku, melainkan ada pemahaman lain yang disebut dengan adjustment ruang. Sonnenfeld dalam Iskandar (2012:47), menyatakan bahwa adjustment ruang adalah manusia dalam berinteraksi dengan lingkungannya, ia mengubah lingkungan agar sesuai dengan keinginannya. Pada hal ini manusia berusaha mempertahankan standarnya. Sebagai contoh, seseorang akan menanam pohon di halaman rumahnya agar udara di sekitar rumahnya menjadi sejuk. Berbeda apabila manusia menggunakan mekanisme adaptasi perilaku, mereka akan menerima saja udara yang tidak sejuk di sekitar rumahnya.

Menurut Iskandar (2012:47), ada beberapa hal yang membedakan mekanisme adaptasi dan adjustment ruang, yaitu: adaptasi dan adjustment. Pengertian adaptasi berkaitan dengan manusia menyesuaikan diri dengan alam, dan manusia tidak berupaya mengatasi lingkungan. Sedangkan adjustment berkaitan dengan manusia mengubah lingkungan sesuai dengan standar yang dimilikinya dan manusia harus memiliki kemampuan untuk dapat 
mengubah lingkungan, baik kemampuan intelektual, skill, maupun uang.

Menurut Paul A. Bell dkk. (Sarwono, 1992: 47-48) tahap paling awal dari hubungan manusia dengan lingkungannya adalah kontak fisik antara individu dengan objek-objek di lingkunggannya. Hasil interaksi individu dengan objek menghasilkan persepsi individu tentang objek tersebut. Jika persepsi batas optimal maka individu dikatakan dalam keadaan homeostatis, yaitu keadaan yang serba seimbang. Jika obyek dipersepsikan di luar batas-batas optimal, maka individu akan mengalami stress sehingga orang tersebut harus melakukan coping untuk menyesuaikan dirinya atau menyesuaikan lingkungan pada kondisi dirinya.

Sebagai hasil dari coping behavior (tindakan penyesuaian) ada dua kemungkinan yang bisa terjadi. Pertama, gagalnya tingkah laku coping menyebabkan stress berlanjut yang berdampak pada pada kondisi dan persepsi individu. Kedua, berhasilnya tingkah laku coping menyebabkan terjadinya penyesuaian antara diri individu dengan lingkungannya (adaptasi) atau penyesuaian keadaan lingkungan dengan diri individu (adjustment) dan berdampak pada kondisi individu maupun persepsinya. Dampak dari tingkah laku coping yang berhasil terjadi berulang-ulang maka kemungkinan terjadi penurunan tingkat toleransi terhadap kegagalan atau kejenuhan dan terjadi peningkatan kemampuan untuk menghadapi stimulus berikutnya. Kegagalan yang berulang, kewaspadaan meningkat, sehingga pada suatu titik akan terjadi gangguan mental seperti keputusasaan, kebosanan, perasaan tak berdaya hingga penurunan prestasi.

Mekanisme adaptasi oleh manusia terhadap lingkungan dilakukan melalui adaptation by adjustment, adaptation by reaction, dan adaptation by withdrawl. Tindakan manusia untuk menolak dengan cara melakukan perubahan fisik terhadap lingkungan agar terjadi kesesuaian yang disebut dengan adaptation by adjustment. Tindakan manusia untuk menolak atau melawan lingkungan dengan cara mengubah perilaku diri agar sesuai dengan lingkungan disebut dengan adaptation by reaction. Tindakan manusia untuk menghindari lingkungan karena ketidakcocokan (ketidaksesuaian) antara manusia dengan lingkungannya dengan cara membiarkan lingkungan dan pindah ke tempat (lingkungan) lainnya dianggap sesuai disebut dengan adaptation by withdrawl.

\section{Santriwati dan Pesantren}

Menurut Kamus Besar Bahasa Indonesia (2005: 997), pengertian santriwati merupakan sebutan bagi santri perempuan, sehingga definisi santriwati mengikuti pengertian 
santri dalam KBBI, yaitu orang yang mendalami agama; orang yang beribadah dengan sungguh-sungguh; orang yang saleh, sehingga menurut pengertian tersebut, santriwati adalah orang perempuan yang mendalami agama (Islam). Penunjukkan status perempuannya ditandai dengan imbuhan "wati" di belakang kata "santri".

Santri biasa tinggal di sekeliling masjid di setiap kota besar maupun kecil di Jawa, yang biasa disebut Kauman (Geertz, 1989: 180). Kebanyakan santri adalah totalistik, yakni menganggap agama Islam sebagai dasar yang fundamental untuk perilaku manusia dalam segala aspeknya (Geertz, 1989: 207-208). Dalam hal mengatasi konflik antara kaum modernis dan konservatif, santri cenderung menyukai penyesuaian daripada perdebatan, dan kritik tak langsung daripada konflik terbuka (Geertz, 1989: 194).

Pesantren merupakan sebuah lembaga pendidikan luar sekolah yang menyelenggarakan program pengajaran pendidikan Agama Islam kepada santri sebagai peserta didik. Departemen Agama RI menyatakan bahwa sebuah lembaga pendidikan dapat disebut sebagai pesantren apabila di dalamnya terdapat lima unsur yaitu: 1) kyai, 2) santri, 3) pengajian, 4) asrama, 5) masjid dengan segala aktifitas pendidikan keagamaan dan kemasyarakatannya. Jadi asrama pesantren merupakan bangunan atau fasilitas tempat tinggal yang berhubungan dengan bangunan pesantren.

Menurut Siradj dalam Herman (2013: 146), secara terminologis dapat dijelaskan bahwa pendidikan pesantren merupakan tempat dimana dimensi ekstorik (penghayatan secara lahir) Islam diajarkan, dilihat dari segi bentuk dan sistemnya berasal dari India. Sebelum Islam menyebar di Indonesia, sistem tersebut telah digunakan secara umum untuk pendidikan dan pengajaran agama Hindu. Setelah Islam masuk dan tersebar di Indonesia, sistem tersebut kemudian diambil oleh Islam. Istilah pesantren sendiri seperti halnya istilah mengaji, langgar, atau surau di Minangkabau, Rangkang di Aceh bukan berasal dari istilah Arab, melainkan India. Selain itu, juga disebutkan bahwa kata pesantren yang berasal dari akar kata " santri" dengan awalan "pe" dan akhiran "an" berarti tempat tinggal para santri. Jika menengok waktu sebelum tahun 60-an, pusat-pusat pendidikan tradisional di Indonesia lebih dikenal dengan sebutan pondok, barangkali istilah pondok berasal dari kata Arab "funduq", yang berarti pesangrahan atau penginapan bagi para musafir.

Bangunan pokok sebuah pondok biasanya terdiri dari sebuah masjid, rumah Kiai, dan sederetan asrama untuk para santri. Pondok tidak mempunyai jadwal yang tetap dan pola 
kehidupannya tidak teratur. Sistem pondok tidak ketat sehingga para murid bisa datang dan pergi semaunya dengan izin yang mudah dari Kiai, asalkan memiliki reputasi yang baik (Geertz, 1989: 242-243).

Pada awal perkembangannya, menurut Geertz (1989: 241-242), pondok atau pesantren merupakan sistem pendidikan tradisional. Sebuah pondok terdiri dari seorang guru atau pemimpin, umumnya seorang haji, yang disebut Kiai, dan sekelompok murid laki-laki yang berjumlah antara tiga atau empat ratus sampai seribu orang, yang disebut santri.

Jenks dan Reisman (1962) dalam Heilweill (1973: 378), mendefinisikan asrama (dormitory) sebagai sarana yang dapat melayani kebutuhan hunian pelajar di sekolah atau universitas. Secara fisik, kondisi asrama umumnya memiliki ruang-ruang yang terdistribusi sepanjang kedua sisi lorongnya, dengan koridor lurus yang terpotong hanya jika ada belokan ke kiri maupun kanan menuju koridor lainnya.

Menurut Heilweil (1973: 379-380), ketidakpuasan di asrama sebagian besar disebabkan oleh desain arsitekturalnya daripada manajemen pengelolaan maupun aturannya. Permasalahan yang dapat muncul adalah: 1) privasi dan isolasi versus penguatan interaksi sosial; 2) proksimitas dan hubungan sosial; 3) aktivitas belajar; 4) Individualisasi.
Menurut De Chiara (1983: 243-246), kamar tidur pelajar merupakan ruangan paling mendasar dalam fasilitas asrama dan harus memfasilitasi aktivitas-aktivitas berikut: 1) belajar (study), 2) tidur (sleep), 3) bersosialisasi (socializing), dan 4) berhias atau berdandan (dressing).

Penataan perabot kamar belajar pribadi diupayakan agar menghemat tempat, tetapi cukup memberi suasana belajar yang nyaman dan privat. Tempat tidur dipilih yang tunggal dan tidak permanen karena setiap individu memiliki pola tidur dan jadwal yang berbeda. Kegiatan bersosialiasi memerlukan penataan agar menghemat ruang dan menciptakan keakraban seperti layaknya suatu keluarga. Perabotan-perabotan yang ada di kamar seringkali diatur dan disesuaikan agar mewadahi interaksi sosial. Antara wanita dan pria memiliki kebutuhan tipe dan volume ruang penyimpanan pakaian yang berbeda. Salah satu penelitian menunjukkan bahwa normalnya, pelajar pria sudah merasa cukup dengan ruang penyimpanan berukuran empat kaki (4 ft) dan empat laci. Unit ruang penyimpanan kombinasi dengan ukuran kecil, akan dengan baik mengakomodasi pilihan pelajar dan memungkinkan pengaturan ruang secara fleksibel. Lemari pakaian dipilih yang tunggal dan permanen untuk mengurangi kecenderungan mahasiswa membuat sekat 
sekat yang mengurangi rasa kesatuan dan persaudaraan di dalam kamar tidur.

Menurut De Chiara (1983: 246-248), kamar tidur berpenghuni banyak (lebih dari dua) seringkali menimbulkan masalah konflik dalam hal interaksi sosial dan aktivitas belajar. Masalah lain yang mungkin terjadi adalah pola pertemanan yang kuat memberikan dampak yang buruk dalam kehidupan akademik pelajar.

Deasy \& Lasswell (1985: 1-11) mengulas lebih jauh mengenai aspek-aspek perilaku manusia di dalam hunian bersama. Berikut ini aspek-aspek perilaku di dalam asrama: 1) keselamatan pribadi (personal safety), 2) hak territorial, 3) Privasi; 4) pembentukan kelompok (friendship). Sebuah asrama tidak lepas dari bahaya kriminal dan kekerasan, yang dapat disebabkan oleh beberapa faktor, seperti peraturan asrama yang kurang ketat dan kurangnya pertahanan desain bangunan asrama. Hak para penghuni walaupun bersifat sementara, bukan berarti tidak penting, karena mereka harus menaati peraturanperaturan yang telah ditetapkan bersama. Peraturan tersebut harus disesuaikan dengan kebutuhan penghuni agar memiliki perasaan teritorial tempat tinggal mereka yang bersifat sementara. Privasi sangat penting bagi penghuni asrama tetapi hal ini sangat sulit didapatkan di dalam asrama karena dihuni oleh banyak orang. Pembentuan kelompok biasanya terjadi pada tahun kedua, dimana pada tahun pertama antar penghuni masih menyesuaikan diri dengan penghuni lain. Pembentukan kelompok ini juga dapat meningkatkan rasa aman (personal safety) dan nyaman di dalam asrama.

\section{Tinjauan Tentang Pesantren Al-Munawwir \\ Krapyak}

Dalam penyelenggaraan pendidikannya, Pesantren Al-Munawwir menyediakan fasilitas asrama yang dikenal dengan sebutan komplek sebagai tempat tinggal bagi para santri maupun santriwati. Komplek santri dan santriwati dipisah dan dibedakan berdasarkan status pendidikannya. Seiring dengan perkembangan dan pertambahan jumlah santri dan santriwati, kebutuhan komplek juga bertambah. Sejak awal berdiri, Pesantren Al-Munawwir tidak membatasi jumlah santri dan santriwati, sehingga pembangunan komplek mengikuti kebutuhan santri. Sudah padatnya lingkungan pondok oleh perumahan warga, mengakibatkan pembangunan komplek tidak bisa lagi dilakukan di pusat pesantren. Oleh karena kondisi tersebut, tidak semua komplek di Pesantren Al-Munawwir berada dalam satu lokasi yang sama.

Permasalahan utama pada perancangan
interior ruang asrama santriwati Pondok
Pesantren Al-Munawir Krapyak adalah


penghuni yang banyak dengan ruang terbatas.

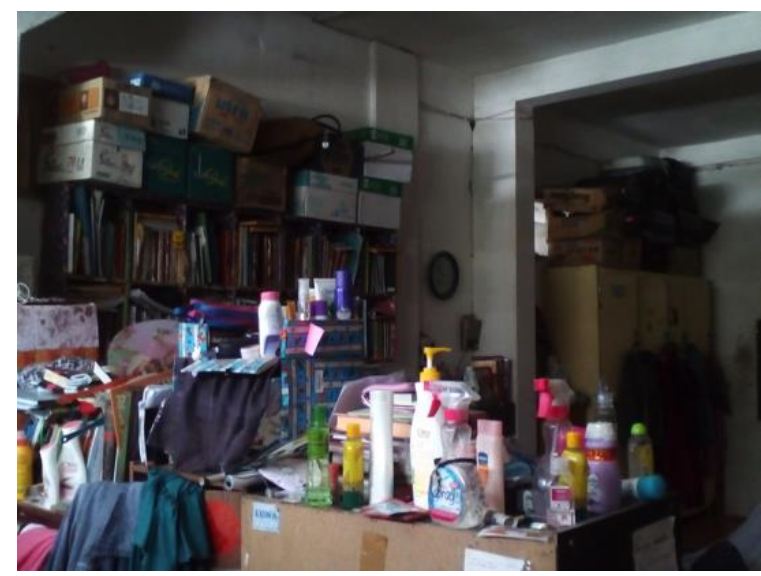

Gambar 1. Penataan Perabot dan Perlengkapan Santriwati yang Tidak Teratur dan terkesan Berantakan (Sumber: Faizah, 2017)

Dari foto di atas dapat diketahui bahwa kebutuhan dan peralatan penghuni (perempuan) yang relatif banyak tidak terfasilitasi dalam perabot. Peletakan yang tidak teratur menajdikan ruang tersebut menjadi sumpeg.

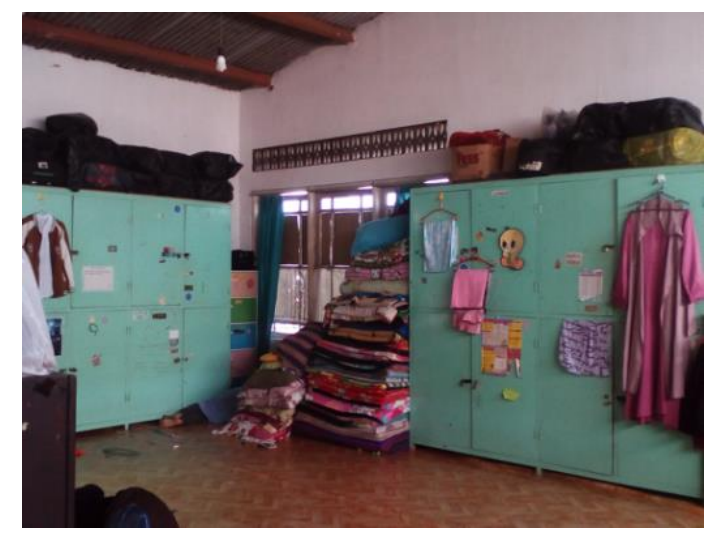

Gambar 2. Almari Pakaian yang Digantungi Pakaian (Sumber: Faizah, 2017)

Dari foto di atas dapat diketahui bahwa almari simpan ternyata tidak dapat menfasilitasi kebutuhan para santriwati yang banyak.

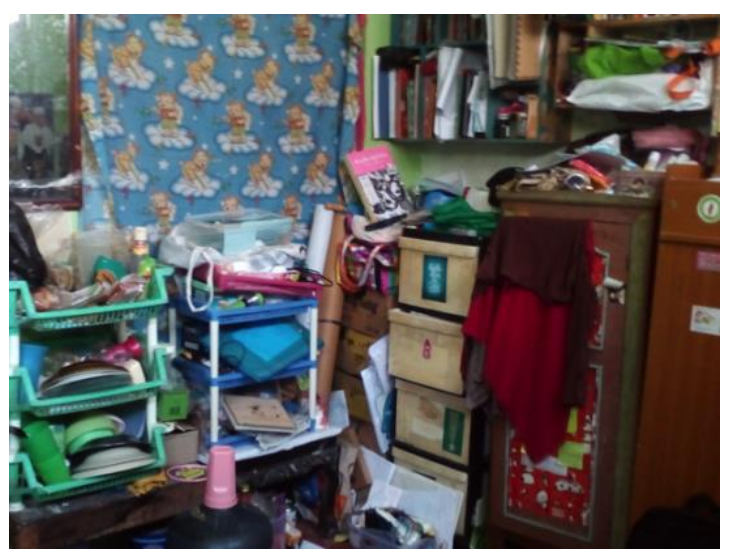

Gambar 3. Perlengkapan Makan yang Bercampur Dengan Almari Buku (Sumber: Faizah, 2017)

karakter perempuan yang secara umum mempunyai kebutuhan yang relatif banyak menjadikan fasilitas-fasilitas yang ada di asrama tersebut menjadi tidak mencukupi, sehingga para santriwati meletakkan kebutuhan mereka scara sembarangan dan tidak tertata.

Dari permasalahan di atas dapat dikatakan bahwa gagasan pemecahan masalah yang akan dilakukan adalah : 1). membuat zona penyimpanan, zona istirahat dan zona sosialisasi terkait dengan privasi dan personal space; 2). mendesain perabot yang simpel namun fungsional sehingga kebutuhan satriwati bisa terfasilitasi di sesuaikan dengan keluasan ruang.

\section{Evaluasi Ruang dan Penghuni}

Aktivitas-aktivitas yang biasa dilakukan santriwati pada kamar tidur komplek R1 
adalah beristirahat (tidur), belajar, menarik diri dari lingkungan (adaptation by bersosialisasi (mengobrol), ibadah (sholat), berpakaian atau dressing (ganti baju, menyetrika). Kondisi kamar tidur komplek R1 yang tidak sesuai dengan kebutuhan atau berada diluar kondisi optimal, mendorong santriwati melakukan penyesuaian. Ada dua bentuk penyesuaian yang dilakukan santriwati dan sesuai dengan teori Sarwono (1992: 108), yaitu: 1). adaptasi yaitu mengubah tingkah laku agar sesuai dengan lingkungan; 2). adjustment, yaitu mengubah lingkungan agar sesuai dengan tingkah laku.

Kondisi kamar tidur kamar tidur komplek R2 yang menjadi stimulus utama terjadinya penyesuaian adalah: 1). keterbatasan ruang dan perabot penunjang aktivitas (seting fisik), 2). penghawaan ruang yang panas terutama di kamar tidur lantai tiga; 3). kurangnya privasi untuk aktivitas belajar, sholat, dan berganti baju.

Tingkat penyesuaian yang dilakukan santriwati bergantung intensitas stimulus : 1 ). jika intensitas stimulus masih dalam batas kendali, santriwati masih bertahan melakukan aktivitas di dalam kamar tidur, namun dengan konsekuensi mengubah tingkah laku (adaptation by reaction) atau merekayasa lingkungan agar sesuai tingkah laku (adjustment); 2). jika intensitas stimulus diluar batas kendali, santriwati menghindar atau

withdrawal).

Santriwati melakukan adjustment dengan merekayasa elemen semifix (perabotan) dan elemen nonfix (perlengkapan) menjadi perabot multifungsi. Kesadaran (awareness) tentang nilai-nilai kesederhanaan hidup di pesantren dan falsafah "nrimo ing pandhum", menyebabkan santriwati lebih cenderung melakukan adaptasi daripada adjustment dalam menghadapi kondisi kamar tidur komplek R1 yang serba terbatas dan apa adanya. Sikap-sikap seorang muslimah yang dikonstruksi oleh kultur agama di pesantren berpengaruh dalam pembentukan perilaku penyesuaian santriwati.

\section{Desain Ruang tidur Asrama}

Berdasarkan hasil analisis data, berikut ini masalah-masalah utama yang dihadapi santriwati pada kamar tidur komplek R1 dan rekomendasi solusi desainnya. Pertama, keterbatasan ruang untuk menampung aktivitas dan perabot penunjangnya. Masalah keterbatasan ruang dapat diatasi dengan penggunaan perabot multifungsi dan perabot yang mudah dibongkar-pasang (knockdown) sehingga praktis dalam penyimpanan. Untuk mengatur jumlah barang santriwati, pihak pesantren perlu menyediakan dan menyeragamkan perabot penyimpanan (almari) dengan desain yang sesuai kebutuhan namun tetap menanamkan nilai-nilai 
kesederhanaan dan menghemat tempat. Menurut penelitian, santriwati juga membutuhkan perlengkapan untuk setrika dan tempat charger. Tempat charger dibutuhkan karena kebutuhan jaman now para santriwati yang sebagian besar mempunyai Hp. Charger dipasang di dekat area komunal supya dapat menyesuaikan kegiatan para santriwati ketika sedang mengobrol.

Kedua, penghawaan ruang yang panas pada siang hari. Berdasarkan keluhan responden, penghawaan menjadi salah satu masalah yang dirasakan. Ruangan terasa panas saat siang hari disebabkan oleh beberapa hal, salah satunya karena ventilasi udara (jendela) tidak dimanfaatkan dengan baik. Jendela yang seharusnya dapat mengalirkan udara sejuk, sebagian besar dibiarkan tertutup dengan pertimbangan ingin menjaga aurat penghuni kamar agar tidak terlihat dari luar. Penggunaan ceilling fan dan exhaust fan di dinding dapat membantu mengatasi ruang panas. Alasan tidak menggunakan AC adalah karena faktor faham kesederhanaa dan daya listrik yang sangat tinggi.

Ketiga, kebutuhan privasi belum tercapai. Aktivitas belajar membutuhkan konsentrasi dan suasana ruang yang memotivasi untuk belajar. Kosentrasi belajar berkaitan dengan kebutuhan privasi. Santriwati mengeluhkan privasi belajar yang belum tercapai karena kondisi kamar tidur berpenghuni banyak menimbulkan gangguan kebisingan yang sulit untuk dihindari. Solusi yang bisa ditempuh atas masalah tersebut adalah menyediakan ruang khusus belajar di luar kamar tidur. Ruang perpustakaan yang sudah ada di komplek R1 dapat dimaksimalkan sebagai ruang belajar santriwati. Pemberlakuan jam belajar di kamar tidur juga dapat diterapkan agar setiap penghuni dapat saling mengkondisikan. Aktivitas yang juga belum terpenuhi kebutuhan privasinya adalah berganti baju. Aktivitas ini berkaitan dengan batasan aurat yang harus terlindung dari pandangan penghuni kamar yang lain. Masalah ini dapat diatasi dengan menyediakan area ganti baju (fitting room) nonpermanen dengan memanfaatkan sudut ruang yang tidak terpakai dan diberi penutup kelambu.

\section{SIMPULAN}

Adanya perilaku penyesuaian yang dilakukan santriwati, baik secara adaptasi maupun adjustment menunjukkan bahwa kamar tidur komplek R1 belum dirancang sesuai kebutuhan-kebutuhan aktivitas di dalamnya. Meskipun kesederhanaan dan pembatasan fasilitas merupakan cara pesantren untuk menanamkan nilai-nilai 
kesederhanaan kepada santriwatinya, hendaknya pihak pesantren juga mempertimbangkan aspek kebutuhan yang dapat meningkatkan kualitas hidup penghuni. Oleh karena itu penting adanya kerjasama antara pihak pesantren sebagai penyelenggara pendidikan dan desainer interior sebagai pihak perekayasa lingkungan, dalam menciptakan lingkungan yang sejalan dengan kebutuhan penghuni dan tujuan pendidikan pesantren itu sendiri.

Hasil penelitian tentang perilaku adaptasi dan adjustment santriwati pada kamar tidur komplek R1 pesantren AlMunawwir ini dapat menjadi bahan pertimbangan dalam meredesain kondisi lingkungan yang masih kurang baik. Untuk mengetahui bagaimana pengaruh lingkungan terhadap prestasi santriwati dan kualitas pendidikan lembaga pesantren, perlu dilakukan penelitian lebih lanjut.

\section{DAFTAR PUSTAKA}

Deasy, C. M \& Thomas E Lasswell Ph.D. (1985). Designing Places for People. New York: Watson-Guptill Publications.

De Chiara, Joseph\& John Callender. (1983), Time Saver Standard For Building Types 2nd edition. Singapore: Mc. Graw-Hill.
Iskandar, Zulrizka. (2012). Psikologi Lingkungan. Bandung: PT Refika Aditama.

Geertz, Clifford. (1989). Abangan, Santri, Priyayi, dalam Masyarakat Jawa. Jakarta : Pustaka Jaya.

Heilweil, Martin. (Desember 1973). "The Influence of Dormitory Architecture on Resident Behavior" dalam jurnal Environment and Behavior. Vol.5/No.4. Michigan : Sage Publications.

Herman, DM. (Juli-Desember 2013). "Sejarah Pesantren di Indonesia" dalam Jurnal Al-Ta'dib. Vol. 6/ No. 2. Kendari: STAIN Kendari.

Sarwono, Salito Wirawan. (1992). Psikologi Lingkungan. Jakarta: PT Gramedia Widiasarana.

Suryanegara, Ahmad Mansur. (2009). Api Sejarah. Bandung: Salamadina.

Tim Penyusun Kamus Pusat Bahasa. (2005). Kamus Besar Bahasa Indonesia. Jakarta: Balai Pustaka.

Tim Media Almunawwir. (2017). Komplek R1 [online]. Last accessed on May 112017 at URL: http:/www.almunawwir.com /komplek-r2/ 